\title{
The Influence of Offline, Online Media and Counterfeit Awareness among Non-Perishable and Non-Food Products in Ghana
}

\author{
Abraham Yeboah $^{1}$, Vida Owusu-Prempeh ${ }^{1} \&$ Samuel Adjei $^{1}$ \\ ${ }^{1}$ Department of Marketing, Sunyani Technical University, Sunyani, Ghana \\ Correspondence: Abraham Yeboah, Faculty of Business and Management Studies, Sunyani Technical University, \\ Sunyani, Sunyani, Ghana. E-mail: yeboah.a@stu.edu.gh
}

Received: October 4, 2017 Accepted: October 26, 2017 Online Published: November 27, 2017

doi:10.5539/ijms.v9n6p31 URL: http://doi.org/10.5539/ijms.v9n6p31

\begin{abstract}
Previous research has shown that counterfeit activity causes major losses to individuals and country's economy in the global market. This is as a result of less awareness being created across various markets. The study introduced an integrated cognitive behavioural theory in order to advance knowledge in such dimension. The aim of this research study is to investigate the influence of offline, online media and counterfeit awareness among non-perishable and non-food products in Ghana. The research mainly assessed offline media such as, television, radio, newspaper, and billboard, as well as online media such as, facebook, linkedIn, whatsapp, and twitter. A sample of 196 respondents was employed using convenient selection method. A self-completed 5 point Likert structured questionnaire survey was the data collection instrument used. The data collected were computed and analysed by multiple regression to determine the significant association between the variables involved in this study. The overall results of the offline media variables revealed that, only radio is found significant association with counterfeit awareness among non-perishable and non-food products in Ghana. Among the variables that are rejected with no significant association with counterfeit awareness involved television, newspaper and billboard. With regard to the results of online media, all the variables were rejected with no significant association with counterfeit awareness among non-perishable and non-food products in Ghana, involved facebook, linkedin, whatsapp and twitter. The study recommends that consequences about using counterfeit product should be explored to ascertain its effect.
\end{abstract}

Keywords: offline media, online media, counterfeit awareness, among non-perishable and non-food products, Ghana

\section{Introduction}

It is observed that the tendency of consumer buying decision making towards counterfeit products is on the rise. The business owners, sales and marketing practitioners use several ways to put products for sales. Hence, demand for counterfeit and illegal goods consumption has not reduced (Hendriana, Mayasari \& Gunadi, 2013). Hendriana et al. (2013); Stravinskiene, Dovaliene and Ambrazeviciute (2014); Kamenidou, Kapoulas and Papadopoulou (2015) discovered that counterfeiting buying decision is attributed to a number of factors, such as price, shop location, personality, scarcity, perception, ethical concern, personal-demographic and psychographic, product, social and buying situation factor. Also, Albers-Miller (1999) stated that buyers of counterfeit product are always in a mysterious situation. Staake et al. (2008) suggested that counterfeit is affecting the activities of different types of industries, and similar study, Spink and Moyer (2011) examined that organisations are failing to alert consumers and regulators about the awareness of counterfeit products in relevant markets. In another study, Jackson, Arver, Banks and Stecher (2010) claimed that men and women are victim to counterfeit buying across different range of markets. Accordingly, it is found that the awareness of faked or imitation products is on a lowered side which makes consumers continually select these products. The manufacturers, suppliers, and retailers have played minimum role to enable consumers become much aware about faked products, and yet they accounted for the sales losses Albers-Miller (1999); Yoo and Lee (2009); Allen (2012); Cademan, Henriksson and Nyqvist (2012). Other study, Joossens, Merriman, Ross and Raw (2010) explained that size of the illicit trade varies between countries from $1 \%$ to about $40-50 \%$ of the market, $11.6 \%$ globally, $16.8 \%$ in low-income and $9.8 \%$ in high-income countries. The total lost revenue is about $\$ 40.5$ billion a year. Again, Siva (2010) suggested that black market in counterfeit drugs is worth billions, but it does untold damage to the health of the 
poorest populations. Furthermore, Yankus (2006) asserted that Counterfeit drugs, is labeled as fake, substandard, adulterated medicines, have become a real and growing threat to global health.

Providing this, past studies examined aspects of counterfeiting, Albers-Miller (1999) found that countries loses billions of dollars annually to counterfeit products, and similar study by Haque, Khatibi and Rahman (2009) revealed that counterfeit generated much challenge to any economic, social as well as cultural safety. In a study, Hendriana et al. (2013) identified factors that affect counterfeiting from the supply-side include illegal supply chain, legal issues, and law enforcement, while the demand-side sees this phenomenon as the result of consumer's inquiry. Also, Allen (2012) showed that counterfeit products have much influence on the economic and social fabric of society. Its affects economic development, particularly those embarked on appropriate activities such as manufacturers, suppliers and distributors. Similarly, Stravinskiene et al. (2013) claimed that economic crisis affected demand for counterfeit copies of luxury goods, which made the shadow economy grow. In another study, Cademan et al. (2012) found that counterfeiting is noted as the wrongdoing. More so, counterfeiting products can be found throughout the global market accounted for 500 billion dollars (Yoo \& Lee, 2009), and similar study found that counterfeits are growing globally which accounted for about 5-7 percent Triandewi and Tjiptono (2013), and a related study, Allen (2012) asserted that counterfeit products are considered as a global market phenomenon, spread across continents, as well as high and low income countries. Additionally, Haque et al. (2009) suggested that, the countries such as China, Thailand, India and Malaysia are notable for counterfeit products, and similar study, Yoo and Lee (2009) revealed that manufacturing counterfeit brands are usually from China, South Korea, Taiwan and South America. In another study, Yoo and Lee (2009) stated that counterfeit market products includes clothing, shoes, watches, leather goods, as well as jewelry. Another study indicated that the counterfeit goods cause harm consumers (Haque et al., 2009), and a similar study, Finlay (2011) revealed that, the counterfeit products such as pharmaceutical market drugs is a major challenge to the integrity of public health systems, as well as harmful to individual health and welfare, and related study, Clift (2010) shows that inferior drugs cause a major threat to human health. A study, Hieke (2010) stated that counterfeiting has damaging effect on the image of a brand that is built on exclusivity and specialty. Furthermore, Vida (2007) shows that product counterfeiting represents a growing problem for legitimate producers of global branded products. Hendriana et al. (2013) suggested that, the rampant copy right infringement has resulted to counterproductive.

These available studies mainly focused on selling and buying perspective that is the theory of reasoned action, consumer decision model, price-quality heuristic theory and perceived risk theory (Yoo \& Lee, 2005). Notably, it is unclear these past studies clearly addressed the concern of consumer's consciousness of counterfeit products. Based on this, the current study is situated to advance knowledge by introduced an integrated cognitive behavioural theory as a result of counterfeit products through empirical findings that are significant to marketing and retail practitioners, policy makers, as well as manufacturers. The integrated congnitive behavioural theory is employed in conjunction with offline, online media applied to the study of counterfeit products. The main purpose of this study is to investigate the influence of offline, online media and counterfeit awareness among non-perishable and non-food products in Ghana.

\subsection{Research Questions}

These research questions were set to guide the objective of the study:

1). What is significant association of the television, radio, newspaper, billboard and counterfeit awareness among non-perishable and non-food products in Ghana?

2). What is significant association of the facebook, linkedin, whatsapp, twitter and counterfeit awareness among non-perishable and non-food products in Ghana?

The subsequent sections reviewed the past studies in line with counterfeiting, followed by the discussions of the methodology, as well as the results findings. The final part discuss the results findings and previous findings.

\section{Literature Review}

\subsection{Theoretical and Empirical Perspectives of Counterfeit}

Marketing, consumer researchers, economics researchers and other disciplines over the years have delved into the concept of consumer counterfeit buying in their own perspectives for which some research findings are discussed here. However, counterfeiting terminology has been used interchangeably in relation to copy, fake, imitation, and or replica.

Chaudhry, Zimmerman, Peters and Cordell (2009) stated that counterfeiting is not a new business phenomenon and is affecting trade for about 2,000 years, and more attention is being paid for fighting counterfeiting problem. 
Also, Staake, Thiesse and Fleisch (2009) claimed that counterfeit trade is found to be a serious threat to various industries, and over the last 30 years, several attempt is being made to understand illicit market. Accordingly, Sabir, Ahmad, \& Razzaq (2013) suggested that counterfeiting is noted as an international issue destroying the real industry, and a similar study, Staake and Fleisch (2008) argued that counterfeit trade is a highly complex phenomenon, and can be considered as a lost battle. Hence, companies need a thorough understanding of the ways of illicit operators, the role of the consumer decision making, and the associated controversies in order to develop a successful brand and product-protection measures. In another research, Joossens et al.(2010) asserted that countries ability to eliminating counterfeiting trade would save millions of premature deaths, and recover billions of dollars for such countries economy. Varese and Bonadonna (2013) claimed that various types of products has been copied today.

In a research conducted by Triandewi and Tjiptono (2013), counterfeiting defined as identical to the original product. Another study conducted by Allen (2013), defined counterfeiting as any practice or conduct prohibited by law and which relates to production, shipment, receipt, possession, distribution, sale or purchase including any practice or conduct intended to facilitate such activity. According to Yankus (2006), the United States of America law defines counterfeit drugs as those sold under a product name without appropriate authorisation, where the identity of the source of the drug is knowingly and intentionally mislabeled in a way that suggests that it is the authentic approved product. It has been further established that counterfeiting definition can be applied to brand name, generic products, or the bulk ingredients used to make the product. Additionally, Eisend and Schuchert-Güler (2006), defined counterfeiting to mean that an original product with a workable brand value worth copying already exists on the market, whilst such product attributes are copied into another product, which is indistinguishable from the original. Based on this, operators of imitation product can set low price as if it were the original. Singh (2010), counterfeit means to produce, manufacture, forge; imitates a product whose exclusive rights belong to the legitimate right holder. It is a kind of a deceit or more loosely that can be termed as a fraud. In Another study (Staake et al., 2009), counterfeiting is defined as illicit trade denotes a wide variety of illegal or non-contractual activities. Among study, Chaudhry et al. (2009) defined counterfeiting as an illegal activity. In a similar research, Edwards and Carpenter (2013) defined counterfeit goods as identical copies of authentic products. Also, Hendriana et al. (2013) counterfeiting refers to production of original copies of products that violate the intellectual property rights of an organisation. This approach can be classified into counterfeit, pirated, imitation, and gray-area goods. The counterfeit or deceptive goods are produced and sold to mislead consumers into believing the products are genuine.

Fam, Waller and Yang (2009) found that many organisations used offensive advertisement to gain consumers awareness about counterfeit products. In a similar research, Stravinskiene et al. (2013) shows that mass production and information overload, which occurred in the recent time has made consumers unknowingly buy an imitation product. Also, Staake at el. (2009) identified that little is known-both in practice and theory-about the mechanism and structure of the illicit market, the tactics of counterfeit producers, consumer behaviour with respect to imitation products and the financial impact on individual companies. A related study, Tang, Tian and Zaichkowsky (2014) noted that consumers frequently select products on the basis of its usefulness over the genuine. Again, (de Matos, Ituassu \& Rossi, 2007) found that consumer intentions to buy counterfeit products have been dependent on the attitudes they have toward counterfeits in relation to price-quality, personal gratification as well as integrity, and a similar study, Chaudhry et al. (2009) identified seven major driving forces behind the worldwide growth of counterfeit goods. These include: (i) low cost, high technology which results in low investment and high profits (ii) globalisation and lower trade barriers (iii) consumer complicity (iv) expansion of channels and markets (v) powerful worldwide brands (vi) weak international and national enforcement, and (vii) high tariffs and taxes. Another study, Edwards and Carpenter (2013) shows that the value conscious, social cost and anti-big business attitude influence consumer's intention to purchase counterfeit fashion products. More so, Gabrielli, Grappi and Baghi (2012) revealed that there has not been any effect between counterfeit and buyer perception towards luxury brands.

According to Hendriana et al. (2013) found that ethical concern and collectivism significantly influenced purchase intention toward counterfeit movies. In another research (Harun, Suki, Bledram \& Hussein, 2012) revealed that attitude towards counterfeit luxury brands has a positive relationship with intention not to purchase counterfeit luxury brands and value conscious, novelty seeking and integrity. Attitude towards counterfeit luxury brands also has a fully mediating effect on the relationship between novelty seeking and intention not to purchase counterfeit luxury brands. In a research, Yoo and Lee (2009) shows that the Korean female students attitude toward counterfeits has been positively related to purchase intention of originals, whilst purchase intention of original product was negatively related to purchase intention of counterfeits. Another study by 
Rahpeima, Vazifedost, Hanzaee and Saeednia (2014) indicated that conspicuous buying has a significant effect on attitude toward counterfeit items, as well as consumer purchases toward imitate products has a significant effect on buying intention. Sabir et al. (2013) revealed that collectivism, perceived quality and economic factors significantly determine consumers' decision making. Walthers and Buff (2008), suggested that the overall measure of attitudes towards counterfeiting today was similar to those in the last ten years, conversely, there are differences in individual attitude towards products. A study by Perez, Castaño and Quintanilla (2010) shows that consumer counterfeit buying has been attributed to three inner benefit: (1) being efficient by optimising their resources; (2) having fun by experiencing adventure, enjoyment, and risk; and (3) fooling others expecting not to be caught. Tang et al. (2014) shows that counterfeiting consumption relate mainly to electronics products, such as DVDs and computer software. Donaldson and Stephens (2010), indicates that palynology has the potential to constrain geographical source(s) of tobacco, particularly if regionally localised species can be recognised among the pollen.

Phau, Sequeira and Dix (2009) states that attitudes do not influence consumer willingness to purchase counterfeit luxury brands. Though, advertisers and strategist should consider putting a more human face on the damaging effects of counterfeiting. Staake and Fleisch (2008) explained that in order for companies to overcome counterfeiting challenges required using Radio Frequency Identification (RFID) as protection technology to support market monitoring, reaction, as well as prevention effort. Carpenter and Lear (2011) revealed that while gender does not moderate the social cost and anti-big business components of consumer attitudes toward counterfeit fashion products, gender does affect non-material culture, such as beliefs about the ethicality of counterfeiting. A study by Hidayat and Diwasasri (2013) noted that counterfeiting consumption in relation to social and personality factors has the most significant impact towards attitudes. Berman (2008) found strategies to detect and reduce counterfeiting activity, through plan which consists of four steps: (1) developing early warning signals of counterfeiting; (2) budgeting to monitor, deter, and remove counterfeits; (3) using demand-side strategies to deter counterfeiting; and (4) using supply-side strategies to deter counterfeiting. Caruana (1997), suggested that non-price determinants, particularly, those relating to perceived product attributes and attitude towards counterfeiting, affect consumers' intention to purchase counterfeit products.

Chakraborty, Allred and Bristol (1996) indicated that cultural element such as ethnocentrism and country of origin of the original manufacturer has jointly influenced consumer perceptions of risk and attitudes about counterfeits. Bian and Moutinho (2009) shows that brand personality has been performed best in determining consideration of purchasing counterfeit. Bartow (2012) explained that there should be a distinction of regulations to support legal goods from imitation products in order to pave clear way for consumer selection. Penz and Stottinger (2005), noted that there has been considerable amount of supply of imitation products which is fast growing across the global market. Though, governments, as well as other stakeholders across the globe have been working hard to minimise counterfeiting activities. Bloch, Bush and Campbell (1993) found that greater number of consumers has selected a counterfeit garment over the genuine good based on price offering comparatively. Marcketti and Shelley (2009), consumers have expressed interest to select non-counterfeit goods which has being a major concern in relation to knowledge and attitude towards counterfeit apparel goods. Manta (2012) discussed that manufacturers need to consider paying more attention to the trademark system which has played significant role in consumers buying decision making. Manley and Cant (2015) also found that small scale organisations managers have been trying to avoid the purchase of fake products.

\subsection{The Offline, Online Media and Counterfeit Awareness}

The integrated congnitive behavioural theory comprised a combination of cognitive behaviours include: (i) cognitive learning model is the acquisition of much external information, (ii) behavioural learning is comprised of much of knowledge, that integrate information about a particular generic concept such as advertisement, (iii) cognitive modelling could be typically used in line with both advertising and personal selling for marketing campaign, and (iv) consumer behaviour modification is employed for inducing consumer behaviors and cognitions which established various aspect consumer processed information on a particular phenomenon. This approach is adopted for the study (Aslin \& Rothschild, 1987). This theory is introduced in order to situate the current study to examine the influence of offline, online media and counterfeit awareness.

\subsubsection{The Offline Media: Television, Radio, Newspaper, Billboard and Counterfeit Awareness}

These offline media outlined play an important role across various markets used to disseminate information to organisation target audience.

\subsubsection{Television}

Khan (2016) claimed that television constitute one of the most important type of media channel used to create 
exposure for organisations products. Television has become a new status symbol even in remote villages. A further advantage of television as an educational media is that it is helpful in teaching practical work. A televised presentation can be as clear as a face-to-face demonstration. Krugman (1965) described that television advertising is noted as a major influencer of buyer behaviour, as well as driving purchasing decision. Also, it generates most profit and among largest communication medium.

\subsubsection{Radio}

Khan (2016), radio is cheap and easily accessible medium. It provide a wide range of information to target audience when used. Also, del Puente and de Huipulco (2010) asserted that radio is an ideal media for marketing fast moving consumer goods, and it can reach wide targeted audience. A large number of people listen to radio while commuting in urban areas and respond to the broadcast of various commercial messages.

\subsubsection{Newspaper}

Khan (2016) stated that newspaper-print media is another important and among most influential non-personal communication channel used by organisations to create awareness. This form of medium is known to contribute a lot for awareness. In another study, Thornton and Wahl (1996) suggested that newspaper has a wide circulation and can reach large target specific demographics that are traditionally more difficult to reach through other mediums. This enable advertisers to more effectively reach smaller, niche audiences, including those in specific locations. Newspapers deliver more flexibility of advertising.

\subsubsection{Billboard}

Taylor, Franke and Bang (2006) established that billboard possessed significant characteristics to the targeted audience as a result of location of the billboard, readability, clarity of the message, use as a tool of integrated marketing communications, powerful visuals, clever creative, and information provision. Also, Taylor et al. (2006) asserted that billboards connect businesses to consumers and constitute the mouth piece of small business. Franke and Taylor (2017), billboards serve as part of the larger category of out-of-home media intended to reach consumers outside the home.

$H_{l}$ : The offline media television, radio, newspaper, billboard has a significant association with counterfeit awareness among non-perishable and non-food products in Ghana.

\subsubsection{The online media: facebook, linkedin, watsapp, twitter and counterfeit awareness}

Social media platforms are also employed by organisations and government agencies as important non-personal tool of communication with their target audience.

\subsubsection{Facebook}

Ramsaran-Fowdar and Fowdar (2013) stated that the most visited online social network is Facebook, founded in 2004 and with over 600 million users and presence in over 70 countries. The Facebook site allows users to create a profile of themselves and explore the profiles of others, gaining an insight into others' lifestyle and interests. Further to this, Facebook is considered as an excellent direct-response marketing platform, which can provide immediate and direct answers to marketing questions and problems within the least time period. Additionally, Paquette (2013) ascertained that facebook has become an avenue where retailers can extend their marketing campaigns to a wider range of consumers. Also, this is a place where consumers can learn more about their favorite companies and the products they sell. Marketers and retailers use facebook platform as another way to reach consumers and provide a new way to shop. Further to this, Stueber and Wurth (2017) discussed that Facebook have quickly become more popular as well more useful by business owners. Consumer marketing and brand management are connected to growing technology-world.

\subsubsection{Linkedin}

Ciprian (2015) revealed that a significant size the world's population has registered with different social media platforms. This means that consumers sign up with any of the social media platform are on the high side and organisation should utilised such opportunities. Also, it is established that there are about 1.74 billion social media users, and linkedin platform play a crucial role in acquiring customers to the businesses. For example, in 2013, 43\% of marketers acquired customers used Linkedin platform.

\subsubsection{Whatsapp}

Bethran (2016) states that many companies have found new possibilities to promote their products through this channel. This approach are mainly used as a non-personal marketing campaign tool. Social media tool like whatsapp still has huge growth potentials regarding offer much support in marketing and sales of organisation 
products. Teng and Yazdanifard (2013), the whatsapp has had a tremendous impact on many aspects of our lives, from daily relations to our business practices. It is easier for organisations and marketers to promote their products.

\subsubsection{Twitter}

Petrović, Osborne and Lavrenko (2010); Bulearca and Bulearca (2010) explained that twitter as a form of medium allows oranisations to stay on top of trends, as well as up to date with what the market is interested in. The used of twitter as a platform for marketing campaigns can reach out to a large number of target audience in order to create more brand awareness. In addition, twitter is a strong tool towards attaining brand recognition and establishing a strong digital marketing campaign. Grafström, Grafström, Falkman and Falkman (2017), twitter is being a useful tool for interaction at all levels among senior managers, as well as executives of an organisations.

$\mathrm{H}_{2}$ : The online media facebook, linkedin, watsapp, twitter has a significant association with counterfeit awareness among non-perishable and non-food products in Ghana.

\section{Methodology}

\subsection{Data Collection and Analysis}

The students and staff of the Sunyani Technical University who shop around various retail and supermarket stores in the township of Sunyani were considered as the population of this study. A convenience sample (non-probability sampling method) of 230 students and staff was selected for the study, whilst 196 questionnaires were retrieved. These categories of the population were chosen purposely because they represent a cross section of consumers who are noted to understand product purchase among non-perishable and non-food products in Ghana. The respondents completed the questionnaire survey on the basis of their own will without any form of inducement. The approach employed for distribution and collection mainly carried out of the University campus, such as visited offices, various University campus streets, as well as the commercial area of the University.

The data collection tools constitutes three main sub-parts. The nature of the instrument designed were captured from the past studies. The first sub-part constitute demographic data; gender, age, marital status and qualification, as well as the second sub-part which consist of consumer involvement / understanding of counterfeit products buying; consumer level of understanding about counterfeit products, and product consumer consider as counterfeit on purchase. Notably, variables or items both first and second part of the questionnaire were arranged to measure frequency was adopted from the paper of Hendriana (2013), and then further modified to suit this study. Further to this, the third sub-part consist of measure the tendency of the offline, online media and counterfeit buying awareness perspective among consumers in Ghana, was adopted from the paper, Sabir et al. (2013), where variables are measured on 5 point interval likert scale ranging from: $1=$ strongly disagree, $5=$ strongly agree. Upon the collecting of data, the questionnaire was pre- tested, refined and finally administered.

The overall data collected 196 out of 230 questionnaires distributed were coded and entered into the Statistical Package for Social Sciences (SPSS) version 20 for analysis and evaluation. The questionnaire survey retrieved rate constituted $85 \%$. Multiple regression was mainly employed to analyse / answer the research questions or objectives. Hence regression employed is suitable for analysing a significant association between categorical variables - that is independent and dependent variables.

\section{Results and Discussion}

\subsection{Demographic Characteristics}

Table 1 presents demographic characteristics of the respondents for the study. Overall, the analysis depicts gender, age, marital status and qualification of respondents. The total number of respondents constitutes 196, in terms of gender, 126 respondents $(64.3 \%)$ were more males than 70 respondents $(35.7 \%)$ which consists of females. With the age of respondents, most of them were between 28-37 years $(38.3 \%)$, followed by those between the ages of $18-27$ years $(28.6 \%)$, next between $38-47$ years $(20.9 \%)$, few were between $48-57$ years $(9.7 \%)$, and $58+$ years $(2.6 \%)$ respectively. In terms of marital status, 113 respondents $(57.7 \%)$ constitute those that were single while about 83 respondents $(42.3 \%)$ were married. Finally, regarding qualification, 90 respondents $(45.9 \%)$ constitute Higher National Diploma, followed by 54 respondents $(27.6 \%)$ those with masters, 28 respondents $(14.3 \%)$ those with a first degree, 10 respondents $(5.1 \%)$ those with $\mathrm{PhD} / \mathrm{DBA}, 8$ respondents (4.1\%) constitutes Diploma in Business Studies (DBS), and about 6 respondents (3.1\%) those with a professional qualification. 
Table 1. Demographic characteristics

\begin{tabular}{llll}
\hline Variable & Category & Frequency & Percentage \\
\hline Gender & Male & 126 & 64.5 \\
& Female & 70 & 35.7 \\
\hline Age & $18-27$ & 56 & 28.6 \\
& $28-37$ & 75 & 38.3 \\
& $38-47$ & 41 & 20.9 \\
& $48-57$ & 19 & 9.7 \\
& +58 & 5 & 2.6 \\
\hline Marital Status & Single & 113 & 57.7 \\
& Married & 83 & 42.3 \\
\hline Qualification & DBS & 8 & 4.1 \\
& HND & 90 & 45.9 \\
& First Degree & 28 & 14.3 \\
& Masters & 54 & 27.6 \\
& PhD / DBA & 10 & 5.1 \\
& Professional & 6 & 3.1 \\
\hline
\end{tabular}

\subsection{Analysis of Consumer Counterfeit Involvement}

Table 2 presents the analysis of consumer counterfeit involvement. In terms of consumer level of awareness among non-perishable and non-food products in Ghana, 75 respondents $(38.3 \%)$ were found average, 70 respondents $(35.7 \%)$ were found high, 35 respondents $(17.5 \%)$ were found very high and also, about 16 respondents $(8.2 \%)$ represent low. Also, in terms of product consider as counterfeit among non-perishable and non-food products in Ghana on purchase, 67 respondents (34.2\%) represent medicinal drug, 34 respondents $(17.3 \%)$ represent cosmetic items, followed by 26 respondents (13.3\%) represent clothes, next 20 respondents $(10.5 \%)$ represent wrist watch, as well as 20 respondents $(10.2 \%)$ represent food items, and about 14 respondents (7.1\%) represent shoes.

Table 2. Consumer counterfeit involvement

\begin{tabular}{llll}
\hline Variable & Category & Frequency & Percentage \\
\hline Consumer Level of Awareness & Low & 16 & 8.2 \\
& Average & 75 & 38.3 \\
& High & 70 & 35.7 \\
& Very High & 35 & 17.5 \\
\hline Product Consider as Counterfeit on Purchase & & & 13.3 \\
& Clothes (wax, shirt or skirt) & 26 & 34.2 \\
& Medicinal Drug & 67 & 10.2 \\
& Wrist Watch & 20 & 17.3 \\
& Cosmetic Items & 34 & 7.1 \\
& Shoes & 14 & 7.7 \\
& Food Items (canned, bottled or plastic) & 15 & 10.2 \\
\hline
\end{tabular}

\subsection{Analysis on Hypotheses}

Table 3 indicates the results obtained on the basis of multiple regression to find the significant association between the Independent variables and the dependent variable among non-perishable and non-food products in Ghana. In order to obtain the results (answer research question 1), the study employed this equation: Counterfeit Awareness $=2.045+0.060 \mathrm{x}_{1}+0.115 \mathrm{x}_{2}-0.005 \mathrm{x}_{3}-0.009 \mathrm{x}_{4}$, where $\mathrm{x} 1$ implies Television, $\mathrm{x} 2$ implies Radio, $\mathrm{x} 3$ implies Newspaper and $\mathrm{x} 4$ implies Billboard. The analysis shows that television, newspaper and billboard are rejected based on their weak association among the variables $(p<0.05)$. Conversely, radio is accepted based on the significant association with counterfeit awareness among the variables involved $(\mathrm{p}<0.05)$. 
Table 3. Regression results for offline media and counterfeit awareness among non-perishable and non-food products in Ghana

\begin{tabular}{|c|c|c|c|c|c|}
\hline \multirow[t]{2}{*}{ Model } & \multicolumn{2}{|c|}{ Unstandardized Coefficients } & \multirow{2}{*}{$\begin{array}{l}\text { Standardized Coefficients } \\
\text { Beta }\end{array}$} & \multirow[t]{2}{*}{$\mathrm{t}$} & \multirow[t]{2}{*}{ Sig. } \\
\hline & $\mathrm{B}$ & Std. Error & & & \\
\hline 1 (Constant) & 2.045 & .239 & & 8.54 & .000 \\
\hline Television & .060 & .046 & .094 & 1.322 & .188 \\
\hline Radio & .115 & .036 & .229 & 3.189 & .002 \\
\hline Newspaper & -.005 & .026 & -.014 & -.191 & .849 \\
\hline Billboard & -.009 & .050 & -.13 & -.180 & .858 \\
\hline
\end{tabular}

Note. a. Dependent Variable: Counterfeit Awareness

Table 4 indicates the results obtained on the basis of multiple regression to find the significant association between the Independent variables and the dependent variable among non-perishable and non-food products in Ghana. In order to obtain the results (answer research question 2), the study employed this equation: Counterfeit Awareness $=2.677+0.048 \mathrm{x}_{1}+0.005 \mathrm{x}_{2}-0.031 \mathrm{x}_{3}-0.038 \mathrm{x}_{4}$, where $\mathrm{x} 1$ implies Facebook, $\mathrm{x} 2$ implies LinkedIn, $\mathrm{x} 3$ implies WhatsApp and $\mathrm{x} 4$ implies Twitter. The analysis shows that facebook, linkedin, whatsapp and twitter are rejected based on their weak association among the variables $(\mathrm{p}<0.05)$.

Table 4. Regression results for online media and counterfeit awareness among non-perishable and non-food products in Ghana

\begin{tabular}{llllll}
\hline Model & \multicolumn{2}{l}{ Unstandardized Coefficients } & $\begin{array}{l}\text { Standardized Coefficients } \\
\text { Beta }\end{array}$ & $\mathrm{t}$ & Sig. \\
& $\mathrm{B}$ & Std. Error & & & \\
\hline 1 (Constant) & 2.677 & .215 & & 12.452 & .000 \\
Facebook & .048 & .049 & .081 & .984 & .326 \\
LinkedIn & .005 & .020 & .020 & .267 & .790 \\
WhatsApp & -.031 & .059 & -.044 & -.523 & .601 \\
Twitter & -.038 & .054 & -.056 & -.709 & .479 \\
\hline
\end{tabular}

Note. b. Dependent Variable: Counterfeit Awareness

The overall results of the offline media variables with the $t$-value and p-value revealed that, only radio is found significant association with counterfeit awareness among non-perishable and non-food products in Ghana $(\mathrm{t}=3.189$, $\mathrm{p}$-value $0.002<0.05)$. Among the variables that are rejected with no significant association with counterfeit awareness involved television $(\mathrm{t}=1.322$, $\mathrm{p}$-value $0.188>0.05)$, newspaper $(\mathrm{t}=-0.191$, $\mathrm{p}$-value $-0.849>0.05)$, and billboard ( $\mathrm{t}=-0.180$, $\mathrm{p}$-value $-0.858<0.05)$. With regard to the results of online media, with the $t$-value and $p$-value shows that all the variables are rejected with no significant association with counterfeit awareness among non-perishable and non-food products in Ghana, which involved facebook $(\mathrm{t}=0.984$, $\mathrm{p}$-value $0.326>0.05)$, linkedin $(\mathrm{t}=0.267$, p-value $0.790>0.05)$, whatsapp $(\mathrm{t}=-0.523$, $\mathrm{p}$-value $0.601>0.05)$, and twitter $(\mathrm{t}=-0.709$, $\mathrm{p}$-value $0.479>0.05)$.

\section{Discussion of Findings}

Table 1 finding depicts the respondents' characteristics that are those involved in counterfeiting buying which support the view that men and women are found in the counterfeit act (Jackson et al., 2010). In terms of Table 2, findings confirmed that demand for fake products among non-perishable and non-food products in Ghana is on the rise, particularly, on medicinal drugs (Yankus, 2006). Further to this, the study confirmed that illicit trade varies between countries (Yankus, 2006), and counterfeit products are noted as a global market phenomenon (Yoo \& Lee, 2009).

The overall hypotheses analysis (Table 3 and 4) results of the offline media, online media and counterfeit awareness among non-perishable and non-food products in Ghana, support the view that consumers are in a mysterious situation. This means that consumers to become much aware about counterfeit products is on the lowered side (Albers-Miller, 1999). Further to this, the findings support the past studies that stakeholders (suppliers, manufacturers, sales professionals and marketers) have not done enough for consumers to understand the negative effect about fake products (Yoo \& Lee, 2009; Allen, 2012).

Additionally, study confirmed previous study by Staake at el. (2009) that little is known - both in practice and theory - about the mechanism and structure of the illicit market. More so, the finding support the view that in order for companies to overcome counterfeiting challenges required using Radio Frequency Identification (RFID) 
as protection technology to support market monitoring, reaction, as well as prevention effort (Staake \& Fleisch, 2008). Conversely, the finding does not support the claimed by Fam, Waller and Yang (2009) that many organisations used offensive advertisement to gain consumers awareness about the counterfeit products, whilst which platform such offensive awareness is being created unknown. Further to this, the finding does not support the view that mass production and information overload, which occurred in the recent time has made consumers unknowingly buy an imitation product Stravinskiene et al. (2013), but how such information overload happened is not clearly stated.

\section{References}

Albers-Miller, N. D. (1999). Consumer misbehavior: why people buy illicit goods. Journal of Consumer Marketing, 16(3), 273-287. https://doi.org/10.1108/07363769910271504

Allen, E. (2012). The illicit trade in tobacco products and how to tackle it. World Customs Journal, 6(2), 121-130.

Aslin, T. M., \& Rothschild, M. L. (1987). An introduction to a cognitive-behavioral perspective of consumer behavior. ACR North American Advances.

Bartow, A. (2012). Counterfeits, copying and class. Houston Law Review, 48, 43.

Berman, B. (2008). Strategies to detect and reduce counterfeiting activity. Business Horizons, 51(3), $191-199$. https://doi.org/10.1016/j.bushor.2008.01.002

Bethran, A. (2016). Impact of Social Media for Marketing Strategy. Multi-Disciplinary Journal of Scientific Research \& Education, 2(11).

Bian, X., \& Moutinho, L. (2009). An investigation of determinants of counterfeit purchase consideration. Journal of Business Research, 62(3), 368-378. https://doi.org/10.1016/j.jbusres.2008.05.012.

Bloch, P. H., Bush, R. F., \& Campbell, L. (1993). Consumer accomplices in product counterfeiting: a demand side investigation. Journal of Consumer Marketing, 10(4), 27-36. https://doi.org/10.1108/07363769310047374

Bulearca, M., \& Bulearca, S. (2010). Twitter: a viable marketing tool for SMEs? Global Business and Management Research, 2(4), 296.

Cademan, A., Henriksson, R., \& Nyqvist, V. (2012). The affect of counterfeit products on luxury brands: An empirical investigation from the consumer perspective.

Carpenter, J. M., \& Lear, K. (2011). Consumer attitudes toward counterfeit fashion products: does gender matter? Journal of Textile and Apparel, Technology and Management, 7(1).

Caruana, A. (1997). Corporate reputation: concept and measurement. Journal of Product \& Brand Management, 6(2), 109-118. https://doi.org/10.1108/10610429710175646

Chakraborty, G., Allred, A. T., \& Bristol, T. (1996). Exploring consumers' evaluations of counterfeits: The roles of country of origin and ethnocentrism. NA-Advances in Consumer Research, 23.

Chaudhry, P. E., Zimmerman, A., Peters, J. R., \& Cordell, V. V. (2009). Preserving intellectual property rights: Managerial insight into the escalating counterfeit market quandary. Business Horizons, 52(1), 57-66. https://doi:10.1016/j.bushor.2008.04.003

Ciprian, P. (2015). The Growing Importance of Social Media in Business Marketing. Quaestus, 7, 94.

Clift, C. (2010). Combating counterfeit, falsified and substandard medicines: defining the way forward? Chatham House London UK.

De Matos, C., Trindade-Ituassu, C., \& Vargas-Rossi, C. A. (2007). Consumer attitudes toward counterfeits: a review and extension. Journal of Consumer Marketing, 24(1), 36-47. https://doi.org/10.1108/07363760710720975

Del Puente, C., \& De Huipulco, C. E. (2010). Role of Radio Advertisements as Behavioral Driver among Urban Consumers.

Donaldson, M. P., \& Stephens, W. E. (2010). Environmental pollen trapped by tobacco leaf as indicators of the provenance of counterfeit cigarette products: a preliminary investigation and test of concept. Journal of Forensic Sciences, 55(3), 738-741. https://doi:10.1111/j.1556-4029.2010.01319.x

Edwards, K. E., \& Carpenter, J. M. (2013). US Consumer Attitudes toward Counterfeit Fashion Products. 
Journal of Textile and Apparel, Technology and Management, 8(1).

Eisend, M., \& Schuchert-Güler, P. (2006). Explaining counterfeit purchases: A review and preview. Academy of Marketing Science Review, 12, 1-22.

Fam, K. S., Waller, D. S., \& Yang, Z. (2009). Addressing the advertising of controversial products in China: An empirical approach. Journal of Business Ethics, 88, 43-58. https://doi.org/10.1007/s10551-008-9832-y

Finlay, B. D. (2011). Counterfeit Drugs and National Security.

Franke, G. R., \& Taylor, C. R. (2017). Public Perceptions of Billboards: A Meta-Analysis. Journal of Advertising, 1-16. http://dx.doi.org/10.1080/00913367.2017.1334248

Gabrielli, V., Grappi, S., \& Baghi, I. (2012). Does counterfeiting affect luxury customer-based brand equity? Journal of Brand Management, 19, 567-580. https://doi: 10.1057/bm.2012.6

Grafström, M., Grafström, M., Falkman, L. L., \& Falkman, L. L. (2017). Everyday narratives: CEO rhetoric on Twitter. Journal of Organizational Change Management, 30(3), 312-322. https://doi.org/10.1108/JOCM-10-2016-0197

Haque, A. K. M., Khatibi, A., \& Rahman, S. (2009). Factors influencing buying behavior of piracy products and its impact to Malaysian market. International Review of Business Research Papers, 5(2), 383-401.

Harun, A. H., Suki, N. M., Bledram, N. A. A. R., \& Hussein, Z. (2012). Why customers do not buy counterfeit luxury brands? Understanding the effects of personality, perceived quality and attitude on unwilligness to purchase. Labuan E-Journal of Muamalat and Society, 6, 14-29.

Hendriana, E., Mayasari, A. P., \& Gunadi, W. (2013). Why do college students buy counterfeit movies? International Journal of E-Education, E-Business, E-Management and E-Learning, 3(1), 62. https://doi:10.7763/ijeeee.2013.v3.194

Hidayat, A., \& Diwasasri, A. H. A. (2013). Factors influencing attitudes and intention to purchase counterfeit luxury brands among Indonesian consumers. International Journal of Marketing Studies, 5(4), 143. http://dx.doi.org/10.5539/ijms.v5n4p143

Hieke, S. (2010). Effects of counterfeits on the image of luxury brands: An empirical study from the customer perspective. Journal of Brand Management, 18(2), 159-173. https://doi.org/10.1057/bm.2010.28

Jackson, G., Arver, S., Banks, I., \& Stecher, V. J. (2010). Counterfeit phosphodiesterase type 5 inhibitors pose significant safety risks. International Journal of Clinical Practice, 64(4), 497-504. https://doi:10.1111/j.1742-1241.2009.02328.x

Joossens, L., Merriman, D., Ross, H., \& Raw, M. (2010). The impact of eliminating the global illicit cigarette trade on health and revenue. Addiction, 105(9), 1640-1649. https://doi: 10.1111/j.1360-0443.2010.03018.x

Khan, A. (2016). Medias Support in Promoting Environment Awareness. International Journal of Scientific Research and Education, 4(8), 5588-559. http://dx.doi.org/10.18535/ijsre/v4i08.01

Krugman, H. E. (1965). The impact of television advertising: Learning without involvement. Public Opinion Quarterly, 29(3), 349-356. https://doi.org/10.1086/267335

Manley, L. L., \& Cant, M. C. (2015). Attitudes of Small Business Owners towards Counterfeit Merchandise: Ethics or Survival? Journal of Economics and Behavioral Studies, 7(4), 48-59.

Manta, I. D. (2012). Hedonic Trademarks. Hedonic. 74 Ohio State Law Journal, 241, 12-20. http://dx.doi.org/10.2139/ssrn.2125252

Marcketti, S. B., \& Shelley, M. C. (2009). Consumer concern, knowledge and attitude towards counterfeit apparel products. International Journal of Consumer Studies, 33(3), 327-337. https://doi:10.1111/j.1470-6431.2009.00748.x

Paquette, H. (2013). Social media as a marketing tool: A literature review.

Penz, E., \& Stottinger, B. (2005). Forget the Areal@ Thingbtake the Copy! An Explanatory Model for the Volitional Purchase of Counterfeit Products. NA-Advances in Consumer Research, 32.

Perez, M. E., Castaño, R., \& Quintanilla, C. (2010). Constructing identity through the consumption of counterfeit luxury goods. Qualitative Market Research: An International Journal, 13(3), 219-235. https://doi.org/10.1108/13522751011053608

Petrović, S., Osborne, M., \& Lavrenko, V. (2010). Streaming first story detection with application to twitter. In 
Human Language Technologies: The 2010 Annual Conference of the North American Chapter of the Association for Computational Linguistics, 181-189.

Phau, I., Sequeira, M., \& Dix, S. (2009). To buy or not to buy a counterfeit Ralph Lauren polo shirt: The role of lawfulness and legality toward purchasing counterfeits. Asia-Pacific Journal of Business Administration, 1(1), 68-80. https://doi.org/10.1108/17574320910942187

Priporas, C. V., Kamenidou, I., Kapoulas, A., \& Papadopoulou, F. M. (2015). Counterfeit purchase typologies during an economic crisis. European Business Review, 27(1), 2-16. https://doi.org/10.1108/EBR-11-2013-0132

Rahpeima, A., Vazifedost, H., Hanzaee, K. H., \& Saeednia, H. (2014). Attitudes toward counterfeit products and counterfeit purchase intention in non-deceptive counterfeiting: role of conspicuous consumption, integrity and personal gratification.

Ramsaran-Fowdar, R. R., \& Fowdar, S. (2013). The implications of Facebook marketing for organizations. Contemporary Management Research, 9(1), 73. https://doi:10.7903/cmr.9710

Sabir, R. I., Ahmad, W. \& Razzaq, A. S. (2013). Factors Affecting Consumers Complicity Towards Counterfeit Mobile Phones in Pakistan. Middle-East Journal of Scientific Research, 18(1), 68-74. https://doi:10.5829/idosi.mejsr.2013.18.1.11666.

Singh, U. (2010). Counterfeit, Medicines and ACTA, 15, 27. http://dx.doi.org/10.2139/ssrn.1725072

Siva, N. (2010). Tackling the booming trade in counterfeit drugs. The Lancet, 376(9754), $1725-1726$. https://doi.org/10.1016/S0140-6736(10)62118-6

Spink, J., \& Moyer, D. C. (2011). Backgrounder: defining the public health threat of food fraud: National Center for Food Protection and Defense. Michigan State University, 30.

Staake, T., \& Fleisch, E. (2008). Countering counterfeit trade: Illicit market insights, best-practice strategies, and management toolbox. Berlin: Springer Science \& Business Media. https://doi.org/10.1007/978-3-540-76947-7

Staake, T., Michahelles, F., Fleisch, E., Williams, J. R., Min, H., Cole, P. H., \& Murai, J. (2008). Anti-counterfeiting and supply chain security. In Networked RFID systems and lightweight cryptography, Springer, 33-43. https://doi:10.1007/978-3-540-71641-9_2

Staake, T., Thiesse, F., \& Fleisch, E. (2009). The emergence of counterfeit trade: a literature review. European Journal of Marketing, 43(3/4), 320-349. https://doi.org/10.1108/03090560910935451

Stravinskiene, J., Dovaliene, A., \& Ambrazeviciute, R. (2014). Factors influencing intent to buy counterfeits of luxury goods. Economics and Management, 18(4), 761-768. http://dx.doi.org/10.5755/j01.em.18.4.5739.

Stueber, H., \& Wurth, S. (2017). A Literature Review of Marketing and Facebook.

Tang, F., Tian, V. I., \& Zaichkowsky, J. (2014). Understanding counterfeit consumption. Asia Pacific Journal of Marketing and Logistics, 26(1), 4-20. https://doi.org/10.1108/APJML-11-2012-0121

Taylor, C. R., Franke, G. R., \& Bang, H. K. (2006). Use and effectiveness of billboards: perspectives from selective-perception theory and retail-gravity models. Journal of Advertising, 35(4), 21-34. https://dx.doi.org/10.2753/JOA0091-3367350402

Teng, N. C., \& Yazdanifard, R. (2013). The Review of the Latest Review of Digital Marketing. Global Journal of Management and Business Research: E-Marketing, 14(2).

Thornton, J. A., \& Wahl, O. F. (1996). Impact of a newspaper article on attitudes toward mental illness. Journal of Community Psychology, 24(1), https://doi.org/10.1002/(SICI)1520-6629(199601)24:1<17::AID-JCOP2>3.0.CO;2-0

Triandewi, E., \& Tjiptono, F. (2013). Consumer intention to buy original brands versus counterfeits. International Journal of Marketing Studies, 5(2), 23. http://dx.doi.org/10.5539/ijms.v5n2p23

Varese, E., \& Bonadonna, A. (2013). Turin University Students Attitude and Perception of Counterfeit and Piracy of Goods: A Preliminary Study.

Vida, I. (2007). Determinants of consumer willingness to purchase non-deceptive counterfeit products and the European Union. Managing Global Transitions, 5(3), 253.

Walthers, A., \& Buff, C. L. (2008). Attitudes towards counterfeiting and counterfeit products: Have they changed. 
Journal of International Business and Economics, 8(3), 79-87.

Yankus, W. (2006). Counterfeit Drugs: Coming to a Pharmacy Near You.

Yoo, B., \& Lee, S. H. (2005). Do counterfeits promote genuine products? Hofstra University.

Yoo, B., \& Lee, S. H. (2009). Buy genuine luxury fashion products or counterfeits? NA-Advances in Consumer Research, 36.

\section{Copyrights}

Copyright for this article is retained by the author, with first publication rights granted to the journal.

This is an open-access article distributed under the terms and conditions of the Creative Commons Attribution license (http://creativecommons.org/licenses/by/4.0/). 